\title{
Analyzing the effects of information technology on supply chain integration: The role of ERP success mediator
}

\author{
Samaneh Alimohamadian* and Farshid Abdi
}

School of Industrial Engineering, South Tehran Branch, Islamic Azad University, Tehran, Iran

\begin{tabular}{l}
\hline C H R O N I C L E \\
\hline Article history: \\
Received October 28, 2013 \\
Received in revised format \\
25 November 2013 \\
Accepted 29 January 2014 \\
Available online \\
February 2 2014 \\
\hline Keywords: \\
Supply Chain Integration \\
Information Technology \\
ERP \\
SEM
\end{tabular}

\section{A B S T R A C T}

\begin{abstract}
This research analyzes the effects of Information Technology (IT) on Supply Chain Integration (SCI) through ERP mediator by proposing a conceptual model among these components. We also hypothesize that three constructs of IT influence on enterprise resource planning (ERP) success and one construct of ERP success influences on SCI. To clarify the relationships among the constructs, structural equation model (SEM) is conducted to examine the model fit and seven hypotheses. The data was collected from three Iranian firms through questionnaire with 23 questions adopted by past researches. The results confirmed that top management support of IT and employees' general IT skills factors of IT enhance ERP success, and ERP success positively influences on Supply Chain Integration, so these two IT factors influence Supply Chain Integration through ERP success. Our data unsupported negative impact of satisfaction with legacy IT system on ERP success.
\end{abstract}

\section{Introduction}

Nowadays, information is considered as a primary tool in decision-making for survival and development of enterprises in supply chain (SC) (Doroudchi \& Nikmehr, 2007). Enterprises in the SC issues are likely to increase control over their suppliers and enhance their supply chain management (SCM) capabilities via gaining power from information (Kashyap, 2011).

Information in supply chain is often used based on two goals (Mashreghi \& Nahavandi, 2010): 1Coordinating the daily activities associated with the production, storage, positioning and transport 2forecasting and planning to estimate future demand and necessary procedures to reach the requirements. Strong distribution and transmission of information can effectively improve all components of SCM. Using information technology to share and accurately transfer information as well as shortening the delay time plays essential role on improvement of SCM implementation. Accurate information can be very efficient in planning and operational decision-making. However, it

*Corresponding author.

E-mail addresses: s.alimohamadian@yahoo.com (S. Alimohamadian) 
is normally difficult to determine the cost of acquisition and installation of information systems such as enterprise resource planning (ERP) to provide this information. Thus, identifying the factors influencing the success of these systems and their deployment order to achieve organizational goals is important (Doroudchi \& Nikmehr, 2007). The study aims to (1) Identify the IT factors influencing ERP success and supply chain integration (2) better understanding of Iranian manufacturing managers and employee's perceptions of relationship between IT, ERP and supply chain integration (3) offer a brief review of the literature on IT, ERP and SCI.

\section{Literature Review}

\subsection{Information Technology (IT)}

Information Technology (IT), as part of a firm's resource portfolio provides a constant competitive advantage ( $\mathrm{Wu} \&$ et al, 2006). Sometimes the terms Information Systems and Information Technology are used, interchangeably, but these are two different concepts. Information System refers to all components and resources necessary to transmit and to process information. In contrast, information technology refers to all hardware, software, network and data management systems, which are essential to exploit system (A.O'brein \& Marakas, 2010). In general, the primary objective of IT is to expedite and to facilitate access to information via the newest communication tools and techniques. IT categories have been studied by many authors, Ifinedo and Nahar (2009) mentioned IT asset, satisfaction with legacy IT system and employees general IT skills as IT organization factors. Byrd and Davidson (2003) studied IT factors in three groups: 1-Top management support of IT 2- IT department technical quality 3- IT plan utilization. Wu et al. (2006) focused on IT advancement and IT alignment dimension of IT.

In this study, we investigate the top management support of IT based on the relative importance of top management for the implementation, execution and success of the organizations. It also studies satisfaction with legacy IT system and employees' general IT skills as IT factors.

\subsection{Enterprise Resource Planning (ERP)}

Prior studies suggest various methods for defining ERP. According to Adaileh and Abu-alganam (2010), ERP is an integrated information system, which integrates enterprise internal function working processes, standardizes internal data processing procedures, and combines the operational data generated by different functions. ERP systems by providing accurate and timely information will lead to supply chain integrity, that is, why many organizations use these systems to establish integration with customers or suppliers or both of them. According to Kashyap (2011) an ERP system can be described as a set of management tools, which balances demand and supply. It also contains the ability to link customers and suppliers into a complete supply chain, employing proven business processes for decision-making, and providing high degrees of cross-functional integration among sales, marketing, manufacturing, operations, logistics, purchasing, financing, new product development and human resources. Therefore, it helps people run their business with high levels of customer service and productivity, and concurrently lower costs and inventories providing the foundation for effective e-commerce. In the literature, the success of ERP systems has been studied in two parts (Adaileh \& Abu-alganam, 2010; Ifinedo \& Nahar, 2009): 1- Technical implementation success of such systems including project management metrics and estimation of cost and time 2ERP success factors after implementation in the organization, that refers to the use of such systems to enhance organizational effectiveness. Gable et al. (2003) developed an ERP system success measurement model according to Delon and McLean (1992) model of information system success, consisting of system quality, information quality, system use, user satisfaction, individual impact and organizational effectiveness. They removed system use and user satisfaction with multi-step data collection and analysis from Delon and McLean model and presented their framework of ERP system success to include system quality, information quality, individual impact and organizational 
effectiveness. Ifinedo and Nahar (2006) developed ERP system success model and added work group impact and quality of a vendor/consultant to Gable et al. model (2003). In this study, ERP success refers to the use of such systems to enhance organizational effectiveness and have been examined according to Ifinedo and Nahar model (2006).

\subsection{Supply Chain Management (SCM)}

Supply chain management is a set of processes that effectively integrates suppliers, producers and consumers together. By definition, a supply chain includes the flow of information up and down the chain to all the entities that are involved. The heart of many of the uncertainties is the result of poor flow of information: it is often inaccurate, untimely, and improperly managed (Byrd \& Davidson, 2003). The definition of SCM according Mentzer et al (2001) is: "The systematic, strategic coordination of the traditional business functions and the tactics across these business functions within a particular company and across businesses within a supply chain, for the purpose of improving the long-term performance of the individual companies and the supply chain as a whole."

The term SCM represents a task of integrating organizational units throughout a supply chain and coordinating the flow of materials, information and finances to meet the customer demands and to improve the competitiveness of a supply chain (Doroudchi \& Nikmehr, 2007). Supply chain integration by integrating internal functions of the organization and establishing relationships among them as well as external processes, suppliers and customers, increase competitive advantage for organizations. Integrated supply chain is a set of communications customers and suppliers who work together to optimize their collective activities (Elahi \& et al., 2009). According to Toloie-Eshlaghi et al. (2011), the importance of supply chain integration can be summarized as "Establishment of the relationships between the internal partners' systems and the external ones, utilizing the common processes in the new method of interaction, integrating the product balance and improvement of the store management, reduction on the delivery time and costs and increase in services and customer satisfactions".

\section{Research Method}

\subsection{The Hypothesis}

Information systems installation such as ERP does not mean success in the use of these systems in order to achieve organizational goals (Ifinedo \& Nahar, 2009). Top management support has long been recognized as the key success and it should include both participation and involvement (Byrd \& Davidson, 2003). Essentially all IT literature has expressed the importance of top management executives to the implementation, use, and success of IT in organizations. It reflects the importance that the top management executives place on IT (Chung et al., 2010).

Hypothesis 1: Top management support of IT positively influences on ERP system success.

ERP systems integrate information in organizations and they are used in many organizations to integrate different parts of the organization, although employee satisfaction from the previous IT systems may lead to rejection of the system by its users. Ifinedo and Nahar (2009) explained that organizational members who are satisfied with existing IT systems do not tend to have positive views about newly acquired systems. Therefore, organizations wary of their old IT systems do adopt newer IT systems, including ERP to stay competitive in the market. Thus, an inverse relationship between "Satisfaction with legacy IT systems" and ERP success would seem appropriate and we hypothesize:

Hypothesis 2: Satisfaction with legacy IT system negatively influences on ERP system success.

Quality end-user training and IT knowledge have been cited among the important factors required for information system (IS) success in general and for ERP implementation success in particular (Kwahk 
\& Lee, 2008; Ifinedo \& Nahar, 2009). Employees who are equipped with such skills are more likely to understand the need for process changes and to value their ERP systems (Ifinedo \& Nahar, 2009).Thus, it is logical to expect that ERP success will be higher where such broad IT skills exist.

Hypothesis 3: Employees general IT skills positively affect ERP system success.

The relationship between ERP and supply chain has been studied to some extent. ERP system utilizes IT and integrates existing systems and operations in organizations and places in a single database available for all units. IT helps managers in a supply chain earn new relationships with customers and suppliers through flow of information and knowledge. This creates an integrated and on time information connection throughout the supply chain from the supplier to the customer (Doroudchi \& Nikmehr, 2007). Yang and $\mathrm{Su}$ (2009) examined the effect of the benefits of ERP system implementation on SCM competency. They believed that the implementation of ERP systems in organizations could create some advantages, which improves the performance of supply chain management (Su \& Yang, 2010). Toloie-Eshlagi et al. (2011) investigated the role of ERP in the contribution and integration of information in the supply chain and it reflects the importance of information and systems such as ERP for better management of supply chain. Adileh and AbuAlganam (2010) implemented ERP system success in organization impact on internal and external supply chain integration.

Hypothesis 4: ERP system success positively affects SCI.

The challenge for organizations today is to understand the factors plays a critical role in utilizing ERP systems capabilities and their implications on SCI to enable them to compete successfully and using their outcomes to improve firm performance (Adaileh \& Abu-alganam, 2010). Therefore, it is expected the information technology mentioned factors affect integrity of the supply chain via ERP success mediator role.

Hypothesis 5: Top management support of IT affects SCI through ERP success mediator role.

Hypothesis 6: Satisfaction with legacy IT system affects SCI through ERP success mediator role.

Hypothesis 7: Employees general IT skills affect SCI through ERP success mediator role.

The structure of the proposed model is shown in Fig. 1.

\subsection{Research instrument development}

Based on the constructs, this study develops a questionnaire and the questions are gathered from questionnaires used in previous researches. The measurement consists of four parts: The general section includes 5 questions, the IT section includes a total of 9 questions, the ERP success includes 6 questions and the supply chain integration includes 5 questions. All items (except general data) were measured using five-point Likert scale with $1=$ strongly disagree and $5=$ strongly agree.

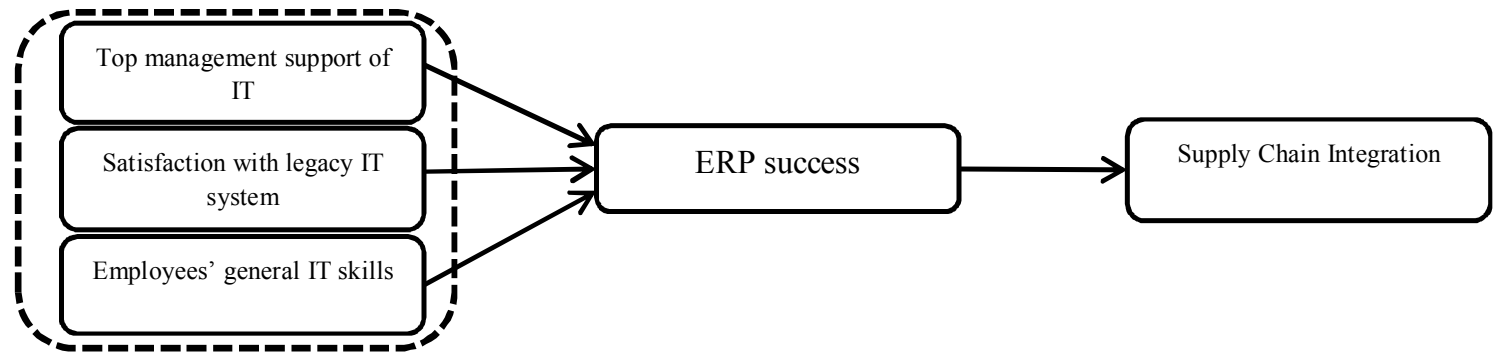

(IT factors)

Fig . 1. Research Model 


\subsection{Population and sampling}

The study population consists of three Iranian companies including 325 employees. We used simple random sampling and selected 163 people (that is enough according Muller(1996) for 2o questions), then information has been gathered and analyzed.

\subsection{Methods of analysis}

This study proposes a structural equation modeling (SEM) to analyze the relationship among IT factors, ERP success and SCI. In this case, there are five latent variables (constructs) and 20 observed variables (measurement items). Confirmatory factor analysis (CFA) was conducted to assess the measurement model; Then, the structural relationship were examined. This measurement model was estimated using AMOS 21.

\subsubsection{Instrument reliability and validity}

To validate this measurement model, content validity, construct validity and convergent validity were assessed. Content validity was established ensuring consistency between the measurement items and the extant literature by interviewing senior practitioners. For the construct validity, the items were tested for scale reliability by Cronbach alpha. The Cronbach alpha ranges from 0.792 to 0.924 for the five constructs, and are thus satisfactory. The construct validity is also tested for convergent validity. Convergent validity assessed by examining composite reliability (C.R.) and average variance extracted from the measures (Yang \& Su, 2009).

Although many studies have used 0.5 as the threshold reliability of the measurement, 0.7 is a recommended value for a reliable construct (Kwahk \& Lee, 2008). The C.R. values range from 0.792 to 0.923 . For the average variance extracted by a measure, a score of 0.5 indicates acceptability (Yang \& Su, 2009). The (AVE) by measures range from 0.576 to 0.836 , which are above or equal 0.5 .Various reliability test result are shown in table 1 .

\section{Table 1}

The results of Cronbach alpha

\begin{tabular}{lccc}
\hline Construct & $\begin{array}{c}\text { Cronbach } \\
\text { alpha }\end{array}$ & $\begin{array}{c}\text { Composite } \\
\text { Reliability }\end{array}$ & $\begin{array}{c}\text { Average variance } \\
\text { Extracted }\end{array}$ \\
\hline Top management support of IT & 0.880 & 0.888 & 0.708 \\
Satisfaction with Legacy IT system & 0.813 & 0.792 & 0.668 \\
Employees general IT skills & 0.924 & 0.923 & 0.836 \\
ERP success & 0.836 & 0.845 & 0.576 \\
Supply Chain Integration & 0.792 & 0.916 & 0.678 \\
\hline
\end{tabular}

\section{Analysis of the results}

Descriptive statistics for demographic variable shows that $80 \%$ of respondents were men and $19 \%$ of them were women. In terms of educational background, $11 \%$ of the participants hold $\mathrm{PhD}$ degree,20\% of them had master degree, $41 \%$ of them had bachelor's degree , $14 \%$ of them hold associate' degree and $13 \%$ of them had diploma. About $65 \%$ of respondents were 31 to 40 years old. In terms of work experience, $23 \%$ of them were worked 5 to 10 years, $40 \%$ of them were worked 11 to 15 years and $35 \%$ of them were worked more than 15 years. About $50 \%$ of participants were expert in job position.

\subsection{Results of the structural equation modeling analysis}

Several goodness of fit indices of measurement model are presented in Table 2. The comparative fit index (CFI) is above 0.90, and the normed fit index (NFI) of the revised model is above 0.60. RMSEA is well below the suggested threshold value of 0.08 . All of these fit indices are acceptable, 
suggesting that the overall structural model provides a good fit with the data. Most of the paths are significant and positive, supporting the hypotheses, except for the satisfaction with legacy IT system not affecting the ERP success. A summary of the hypotheses test results is provided in Table 3.

\section{Table 2}

Fit indices of structural model

\begin{tabular}{lllll}
\hline$\chi 2 / \mathrm{df}<3.00$ & CFI $>0.90$ & NFI $>0.60$ & GFI $>0.90$ & RMSEA $<0.08$ \\
\hline 1.943 & 0.95 & 0.87 & 0.98 & $\mathbf{0 . 0 4 7}$ \\
\hline
\end{tabular}

Table 3

Summary of results

\begin{tabular}{|c|c|c|}
\hline Hypothesis & Path coefficient & Result \\
\hline Top management support of IT $(\rightarrow)$ ERP system success (H1) & 0.447 & supported \\
\hline Satisfaction with legacy IT system $(-\rightarrow)$ ERP system success (H2) & -0.052 & Not supported \\
\hline Employees general IT skills $(\rightarrow)$ ERP system success (H3) & 0.463 & supported \\
\hline ERP system success $(\rightarrow)$ Supply chain integration $(\mathrm{H} 4)$ & 0.738 & supported \\
\hline $\begin{array}{l}\text { Top management support of IT }(\rightarrow \text { ) supply chain integration } \\
\text { Moderated by ERP system success }(\mathrm{H} 5)\end{array}$ & 0.289 & supported \\
\hline $\begin{array}{l}\text { Satisfaction with legacy IT system }(\rightarrow) \text { supply chain integration } \\
\text { Moderated by ERP system success }(\mathrm{H} 6)\end{array}$ & -0.138 & Not supported \\
\hline $\begin{array}{l}\text { Employees general IT skills }(\rightarrow) \text { supply chain integration Moderated by ERP system } \\
\text { success (H7) }\end{array}$ & 0.386 & supported \\
\hline
\end{tabular}

Note: $(\rightarrow)$ positive relationship, $\overline{(-} \rightarrow)$ negative relationship

\section{Discussions and Conclusion}

In this study, we have examined the relationships among some IT factors, ERP success and SCI. As Table 3 shows, our data supports five out of the seven hypotheses. The hypotheses $\mathrm{H}_{1}$ and $\mathrm{H}_{3}$ are strongly supported $(0.447,0.463, \mathrm{p}<0.001)$, demonstrating that ERP success was positively impacted by top management support of IT and employees general IT skills. This proposes that ERP success level might be developed in firms where there are more top management support of IT and employees general IT skills. The $\mathrm{H}_{2}$ was related to the effect of satisfaction with legacy IT system on ERP success and the result was unsupported $(-0.052, p>0.05)$, representing that firms can be satisfied with their existing IT systems and still assess the success of their newly acquired ERP, positively. A reasonable explanation for the lack of support for $\mathrm{H}_{2}$ (from top- and mid-level manager viewpoints in the study's region) might be related to the ERP system adoption such as best practices by employees although they are very satisfied with their old IT systems.

Our data analysis supported $\mathrm{H}_{4}(0.738, \mathrm{p}<0.001)$. The result shows that a positive relationship between ERP system success and supply chain integration exists. This suggests that SCI level might be higher in firms where there is more ERP success. Since hypotheses $\mathrm{H}_{1}$ and $\mathrm{H}_{4}$ are accepted, it can be concluded that hypothesis $\mathrm{H}_{5}$ is also supported. The $\mathrm{H}_{5}$ concerning the impact of top management support of IT on supply chain integration through ERP success intermediary role, this suggests that SCI level might be improved in firms where there are more top management support of IT.

The $\mathrm{H}_{6}$ related to the effect of satisfaction with legacy IT system on SCI via ERP success mediator role is not confirmed because $\mathrm{H}_{2}$ is not supported and satisfaction with legacy IT system does not influence on ERP success. Our data analysis also supported $\mathrm{H}_{7}$, demonstrating that SCI was impacted by employees general IT skills through ERP success mediator role. This proposes that SCI level might be developed in firms where there are more employees general IT skills.

In summary, the results of the data analysis confirmed that top management supported IT and employees' general IT skills factors of IT could enhance ERP success. In addition, ERP success positively influences supply chain integration. Our data unsupported negative impact of satisfaction with legacy IT system on ERP, so the mediator role of ERP success between satisfaction with legacy 
IT system and SCI was not supported. Therefore, the managers who are looking to improve ERP success and consequently supply chain integration in their organizations should increase top management support of IT and employees general IT skills.

\section{Acknowledgement}

The authors would like to thank the anonymous referees for constructive comments on earlier version of this paper.

\section{References}

Adaileh, M., \& Abu-alganam, K. (2010). The Role of ERP in Supply Chain Integration. International Journal of Computer Science and Network Security, 10(5), 274.

Byrd, T. A., \& Davidson, N. W. (2003). Examining possible antecedents of IT impact on the supply chain and its effect on firm performance. Information \& Management, 41(2), 243-255.

Chung, S. H., Tang, H. L., \& Ahmad, I. (2010). Modularity, integration and IT personnel skills factors in linking ERP to SCM systems. Journal of Technology Management \& Innovation, 6(1), $1-3$.

Delon, W. \& McLean, E. (1992). Information systems success: the quest for the dependent variable. Information Systems Research, 3(1), 60-95.

Doroudchi, M., \& Nikmehr, N. (2007). Study on Importance and Utilization Information Technology in Supply Chain. The forth e-commerce conferance. Tehran.

Gable, G. G., Sedera, D., \& Chan, T. (2003). Enterprise systems success: a measurement model. Association for Information Systems. Twenty-Fourth International Conference on Information Systems, Dec. 14-17, Seattle, USA.

Elahi, S., \& et al. (2009). Provide a model to explain the role of information technology in supply chain management integration. Sixth International Conference on Information and Communication Technology Management.

Ifinedo, P., \& Nahar, N. (2006). Quality, impact and success of ERP systems: a study involving some firms in the Nordic-Baltic region. Journal of Information Technology Impact, 6(1), 19-46.

Ifinedo, P., \& Nahar, N. (2009). Interactions between contingency, organizational IT factors, and ERP success. Industrial Management \& Data Systems, 109(1), 118-137.

Kashyap, A. (2011). Impact of ERP implementation on Supply Chain Management. International Journal of Computer Applications in Engineering Sciences, 1(4).

Kwahk, K. Y., \& Lee, J. N. (2008). The role of readiness for change in ERP implementation: Theoretical bases and empirical validation. Information \& Management, 45(7), 474-481.

Mashreghi, M., \& Nahavandi, N. (2010). The Role of Information Technology on Supply Chain Performance with an Emphasis on the Integration and Flexibility Case Study of Automobile Parts Company. First International Conferance on Management,Innovation and Entrepreneurship. Shiraz.

Mentzer, J. T., DeWitt, W., Keebler, K. S., Min, S., Nix, N. W., \& Smith, C. D. (2001). Defining supply chain management. Journal of Business Logistics, 22(2), 1-25.

Muller, R.O. (1996). Basic Princnples Modeling. NY:Springer.

O’Brien, J. A., \& Marakas, G. (2010). Introduction to Information systems. $15^{\text {th }}$ ed.

Su, Y.F., \& Yang, C. (2010). Why are enterprise resource planning systems indispensable to supply chain management?. European Journal of Operational Research, 203(1), 81-94.

Su, Y.F., \& Yang, C. (2010). A structural equation model for analyzing the impact of ERP on SCM. Expert Systems with Applications, 37(1), 456-469.

Toloie-Eshlaghi, A., Asadollahi, A., \& Poorebrahimi, A. (2011). The role of enterprise resources planning (ERP) in the contribution and integration of the information in the supply chain. European Journal of Social Science, 20, 16-27. 
Wu, F., Yeniyurt, S., Kim, D., \& Cavusgil, S. T. (2006). The impact of information technology on supply chain capabilities and firm performance: a resource-based view. Industrial Marketing Management, 35(4), 493-504.

Yang, C., \& Su, Y. F. (2009). The relationship between benefits of ERP systems implementation and its impacts on firm performance of SCM. Journal of Enterprise Information Management, 22(6), 722-752. 